\title{
FACEBOOK I INNE SERWISY SPOŁECZNOŚCIOWE W KOMUNIKACJI MARKETINGOWEJ MAREK MOTORYZACYJNYCH
}

\author{
Abstract \\ FACEBOOK AND OTHER SOCIAL MEDIA SERVICES IN MARKETING \\ COMMUNICATION OF AUTOMOTIVE BRANDS
}

The aim of this article is to present the possibilities and scope of the use of Facebook and some other selected social media services in marketing communication of automotive brands in Poland. The theoretical basis of scholarly literature relating to the described problem. In the empirical part, the results of the author's own research are presented, on the topic of social networking sites in marketing communications of mentioned companies. For the purposes of this study audit of web sites content (the way of communicating about possessing profiles on sites, the location of social plugins in the structure of the web page) and social media profiles of each brand was carried out. On this basis, the diagnosis of the state of the current use of social media in promotional programs of surveyed entities was done.

Key words: social media, marketing communication, Facebook, Instagram, Pinterest

\section{Wstęp}

Liana „Li” Evans [2011, s. 11] już przed kilku laty zauważyła, że „nowe technologie są bardzo ważne, ponieważ pomagają nam nieustannie ulepszać samych siebie. To innowacje kształtują oblicze Internetu i wpływają na model funkcjonowania wielu firm. Ewolucja technologiczna może nawet całkowicie odmienić dany model biznesowy". Takie właśnie zmiany bez wątpienia dokonały się za sprawą mediów społecznościowych. Przewartościowały one całkowicie model komunikacji na linii firma-klient w większości branż, włączając motoryzacyjną. 
Podstawowym narzędziem komunikacji w Internecie jest serwis WWW. Jednak współczesny dynamiczny rozwój marketingu społecznościowego sprawia, że coraz częściej podstawą budowania tożsamości całego przedsiębiorstwa lub poszczególnych marek w sieci są media społecznościowe, do których należy zaliczyć [Podlaski 2011, s. 36-79]:

- duże portale - obsługujące masowe społeczności, na przykład Facebook, Google+, NK.pl;

- portale biznesowe - obsługujące społeczności profesjonalistów, na przykład LinkedIn, GoldenLine;

- portale z filmami i zdjęciami, na przykład YouTube, Flickr, Instagram, Pinterset;

- blogi;

- mikroblogi, na przykład Twitter;

- portale z artykułami, na przykład iThink, Artelis;

- wykopywarki, na przykład Wykop, Digg;

- własny serwis społecznościowy.

Przedstawiona klasyfikacja nie uwzględnia wszystkich typów mediów społecznościowych. Bez problemu można dokonać dalszego podziału ze względu na ich tematykę, rodzaj, funkcje, odbiorców itd.

Należy zauważyć, że o istnieniu własnych profili w mediach społecznościowych można komunikować za pośrednictwem własnej strony WWW, a część z wymienionych narzędzi można włączyć w strukturę strony (jak blogi). Wykorzystanie mediów społecznościowych jest pożądane nie tylko $\mathrm{z}$ uwagi na możliwość promocji (również pozycjonowanie) własnej strony, ale także z wielu innych, wymienionych niżej, względów [Podlaski 2011, s. 36-79].

- Użytkownicy portali społecznościowych akceptują obecność w nich firm czy poszczególnych marek i interesują się daną marką nie tylko przez ciekawość. Liczą na skierowane do nich konkursy, promocje itp. Podobnie jak w innych miejscach w sieci poszukują ciekawostek i informacji dotyczących ich ulubionych marek.

- Portale społecznościowe pozwalają na nieinwazyjne prezentowanie treści (choć są od tego odstępstwa) - na przykład na Facebooku firmy mają możliwość tworzenia własnych profili, a użytkownicy sami decydują, czy chcą dołączyć do fanów danej firmy i śledzić publikowane treści.

- Firma ma szansę na wzmocnienie wizerunku, wiarygodności i zaufania przez dłuższe uczestnictwo w życiu portali społecznościowych oraz ciągły kontakt $\mathrm{z}$ użytkownikami.

- Informacja zwrotna od użytkowników. Media społecznościowe umożliwiają nawiązanie relacji z interesariuszami firmy na zupełnie nowym poziomie. Można nawiązać bezpośredni kontakt oraz uzyskać niezwykle cenne informacje na temat działalności firmy lub marki. 
- Media społecznościowe dają szeroki dostęp do publiczności, co pozwala, dzięki rozmaitym działaniom adresowanym do zdefiniowanych grup odbiorców, realizować różnorodne cele komunikacji.

\section{Facebook - najpopularniejszy serwis społecznościowy wśród marek samochodowych}

Patrząc przez pryzmat marketingu, za najlepszy przekaz wizerunkowy uznaje się taki, który zostanie uznany przez odbiorców za przydatną, wartościową informację, a nie reklamę [Łebkowski 2009, s. 156]. Umiejętne wykorzystanie Facebooka w komunikacji marketingowej może zaowocować tym, że firma, wysyłając komunikaty, zbuduje trwałe relacje $\mathrm{z}$ konsumentami, takie które nie zakończą się wraz z prowadzoną kampanią [Rak 2011, s. 99]. Oznacza to, że poprawnie stworzony, wiarygodny przekaz zostanie odebrany przez otoczenie pozytywnie i będzie powielany dalej przez odbiorców. Poza tym nieformalna komunikacja między konsumentami dotycząca marki często okazuje się znacznie skuteczniejsza od prowadzenia standardowych działań promocyjnych [Brunk 2010, s. 278]. Już sama idea i mechanizm działania Facebooka pomagają w pobudzaniu dyskusji na temat firmy czy marki, które przez to stają się fascynujące, a konsumenci przyjmują role ambasadorów [Hughes 2008, s. 38]. Dzięki takiemu rozgłosowi przedsiębiorstwom jest łatwiej wyróżnić się spośród konkurencji. Założeniem powinno być takie działanie, które sprawi, że konsumenci (w tym przypadku jednocześnie internauci) zaczną odczuwać, iż przynależą do czegoś znaczącego, co ma duże znaczenie dla ich życia zarówno pod względem ekonomicznym, jaki i osobistym. Strategia taka opiera się na zasadzie, że im bardziej wizerunek danej firmy będzie rozpowszechniony, a co za tym idzie dotrze do większego grona odbiorców, tym bardziej będzie skuteczny [Evans, Schmalensee 2010, s. 37]. Wydaje się, że w branży motoryzacyjnej jest to możliwe do osiągnięcia, ponieważ sympatie (czasami też antypatie) dla marek samochodowych u wielu osób wyzwalają duże emocje, a tam, gdzie one się pojawiają, łatwiej jest z kolei o interakcję z odbiorcami.

Istotne jest pozyskanie wartościowych fanów, ponieważ liczyć się będzie nie tylko, ilu ich będzie, ale także, jacy będą. Wagę tego spostrzeżenia zaprezentował Don Bartholomew w modelu działań prowadzonych w mediach społecznościowych (rysunek 1) - EEIA (ang. Exposure, Engagement, Influence, Action). Żeby działania w social media przyniosły oczekiwany efekt, trzeba po pierwsze pozyskać odbiorców - zbudować zasięg. W tym przypadku pozyskanie konkretnych fanów, a więc $\mathrm{z}$ grupy docelowej, czyli osób potencjalnie zainteresowanych komunikacją danej marki motoryzacyjnej, pozwoli zrealizować krok drugi, w którym pozyskaną społeczność należy zaangażować w komunikację z tą właśnie firmą/marką. Po trzecie (opcjonalnie) trzeba zbudować więź między społecznością a danym podmio- 
tem. Dopiero po dokonaniu wymienionych działań można się spodziewać akcji ze strony konsumenta [Rak 2012a, s. 63] - w zależności od celów prowadzonych działań komunikacyjnych.

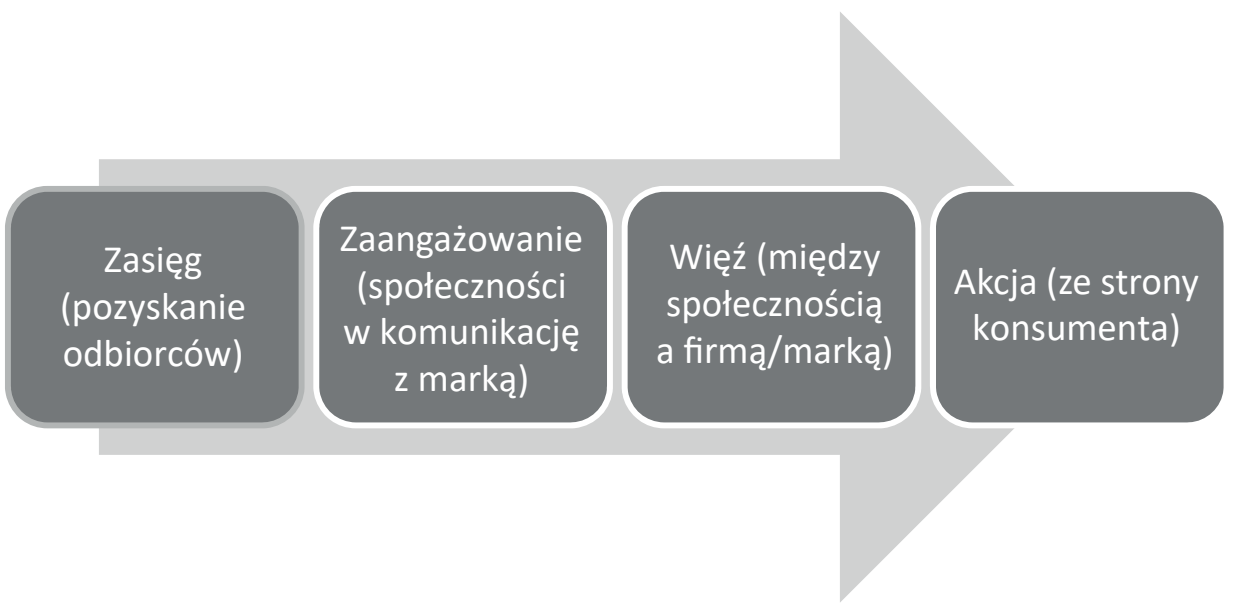

Rysunek 1. Model EEIA Dona Bartholomew

Źródło: opracowanie własne na podstawie http://metricsman.worldpres.com (dostęp: 14.07.2014).

Niektóre branże idealnie nadają się do prowadzenia komunikacji w mediach społecznościowych, inne mniej. Dane Socialbakers ${ }^{1}$ pokazują, że do najpopularniejszych pod względem liczby fanów należą kolejno branże: sportowa, mody, żywnościowa, FMCG i rozrywkowa. Nie zmienia to faktu, iż dla każdej firmy można wymyślić coś, co będzie zgodne z jej strategią i wizerunkiem [Rak 2012b, s. 8]. Przykładem firmy z trudnej branży motoryzacyjnej, która podjęła działania (w zakresie B2B i B2C), łamiące konwencję komunikacji na Facebooku, jest Volkswagen Polska. Na profilu firmy komunikacja świadomie różnicowana jest na sprzedażową oraz luźniejszą, o charakterze lifestyle’owym. Dzięki temu sam fanpage nie jest nachalny, a wprowadzane treści zbliżają markę do fanów, akcentując przy tym jej atuty. Posty prezentują walory poszczególnych modeli samochodów, formaty są zróżnicowane, a treść tak wykreowana, by wywołać zaangażowanie fanów. Zastosowano między innymi nietypową dla profilu motoryzacyjnego formę - zagadki. Dzięki niej fani wciągani są w zabawę, a przy okazji dowiadują się wielu ciekawych rzeczy o marce. W ten sposób odbiorcy nie mają poczucia, że zalewa ich masa treści prosprzedażowych, nie przytłaczają ich liczby do zapamiętania i jaskrawe wykrzykniki.

1 Źródło: Socially Devoted Q4: In Customer Care, Timing is Everything, https://www.socialbakers.com/blog/2082-socially-devoted-q4-in-customer-care-timing-is-everything (dostęp: 2.07.2017). 
Volkswagen, opowiadając o swojej marce obrazami, osiąga dwa cele: eksponuje atuty samochodów w połączeniu ze stosowaną zaawansowaną technologią oraz prezentuje ich walory estetyczne. Informacje o aktualnych promocjach czy akcjach prosprzedażowych zamieszczanie są niejako przy okazji. Przykładem mogą być posty mówiące o wprowadzeniu na polski rynek nowej odmiany najpopularniejszego modelu marki - golfa w odmianie „R”. Dzięki atrakcyjnej treści post zyskał blisko 700 „lajków”, angażując ponad 960 fanów, wykorzystując przy tym ograniczony zasięg wpisu ponad 30 tysięcy w ciągu zaledwie trzech godzin. Innym przykładem jest zadanie zagadki. Fani zobaczyli zdjęcia przykrytego samochodu, ich zadaniem było odgadnąć, jaki to model (chodziło o golfa GTI). Wpis ten otrzymał ponad 230 komentarzy w ciągu niecałych dwóch godzin. Kolejnym, równie skutecznym posunięciem, które wygenerowało ponad 150 komentarzy w niespełna godzinę, było zadanie fanom otwartego pytania o liczbę kilometrów, jaką przejechali w danym dniu. Użytkownicy lubią, gdy marki dają im możliwość opowiedzenia o sobie czy podzielenia się, tak jak w tym przypadku, swoimi motoryzacyjnymi osiągnięciami. Ogólnie pod postem pojawiło się ponad 500 komentarzy, które wygenerowały zasięg na poziomie ponad 26 tysięcy osób, co stanowiło $50 \%$ użytkowników fanpage’a (liczy ponad 50 tysięcy osób). Jest to duży sukces, ponieważ według założeń algorytmu Edge Rank posty powinny docierać do $10 \%$ fanów.

Inną ciekawą inicjatywą była stworzona przez markę aplikacja „Małe jest wielkie!", która stanowiła element kampanii wprowadzającej na rynek miejski model up! Interaktywna gra na Facebooku pozwalała na odbycie wirtualnej jazdy testowej i sprawdzenie funkcjonalności „małego lecz wielkiego” volkswagena. Aplikacja zaangażowała ponad 4600 użytkowników, dając marce prawie sześć tysięcy nowych fanów w ciągu trzech tygodni. Fani profilu łącznie na grze spędzili prawie 20 godzin. Tym samym przez zabawę poznawali funkcjonalności nowego produktu.

Przykład ten pokazuje, jaki powinien być spójny w każdym aspekcie fanpage na Facebooku. Starannie przygotowane grafiki VW, ciekawe albumy i animowane zagadki składają się na przyciągającą uwagę użytkowników estetykę. Do tego dochodzą działania crossmediowe, jak konkurs na Instagramie „Beetle Story” - marka zbudowała popularność profilu w nowym serwisie społecznościowym oraz uzyskała ciekawą konwersję fanów z i do Facebooka. Zdarza się także, że fani zaskakują moderatorów swoją postawą, przełamując schematy biernego sposobu korzystania z portali społecznościowych, gdy jedynie chłonie się treści, nie angażując $\mathrm{w}$ ich dokładne poznanie. Fani przysyłają na przykład wiadomości z prośbą o komentarz, odpowiedź na zagadkę czy rozstrzygnięcie, czyja odpowiedź była najbardziej kreatywna. Volkswagen chętnie wchodzi w dialog z fanami, szybko udziela odpowiedzi na nurtujące ich pytania. To wszystko zbliża markę do klientów i sprawia, że odbiorcom nie wydaje się ona odległa, a przeciwnie: że jest tworzona przez ludzi takich samych jak oni [Pająk 2014, s. 73-76]. Właśnie taki cel powinien przyświecać działaniom komunikacyjnym, nie tylko na Facebooku, ale w mediach społecznościowych w ogóle. 


\section{Wykorzystanie portali z filmami i zdjęciami do promocji samochodów}

Obecnie Internet znacząco upraszcza komunikację. Szczególną rolę w jej procesie odgrywa coraz silniejsza ekspozycja elementów wizualnych: zdjęć, grafik, infografik, filmów, wideostorytellingu. Na tej podstawie rozwijają się serwisy o naturze obrazkowej, których przedstawicielami są między innymi YouTube, Pinterest czy Instagram [Woźniakowski 2013, s. 155-156].

Współczesne społeczeństwo reprezentuje cywilizację i kulturę obrazkową, której początki stanowiły niewinne rysunki malowane na skałach tysiące lat temu. Następnie przyszedł czas na malarstwo, ilustracje w pierwszych książkach, gazetach aż do cyfrowych zdjęć i realistycznych komputerowych grafik. Można wysunąć tezę, że obrazy, zdjęcia i grafiki zdominowały współczesne media [Jakubiak 2014].

Tę sytuację mogą wykorzystać właśnie firmy motoryzacyjne, tworząc własne profile na YouTube i zamieszczając w nim filmy, reportaże pokazujące, jak dany model był tworzony, testy samochodów, relacje z targów motoryzacyjnych i wiele innych, jak robi to na przykład Škoda. Profil czeskiej marki jest spersonalizowany, wyglądem nawiązuje do firmowej strony WWW. Na profilu wyraźnie komunikowana jest obecność firmy w innych mediach społecznościowych (Facebook i Google+). Filmy pogrupowane są na kilkanaście kategorii, między innymi znajdują się tu playlisty poświęcone poszczególnym modelom samochodów, a także konkursowi „Auto muzyka”, „Szkoła Auto” i inne. W części „Auto muzyka” prezentowane są filmy wywiady z jurorami konkursu, m.in. Andrzejem Smolikiem, Fiszem, Kasią Nosowską, Wojciechem Waglewskim, Melą Koteluk i Piotrem Metzem, oraz wideo na temat idei konkursu, wywiady z uczestnikami i materiały pochodzące z innych mediów, w których mówiono o projekcie (np. fragmenty programu Dzień Dobry TVN). W konkursie, trwającym od marca do maja 2014 roku, typowano najlepszą muzykę do słuchania za kierownicą. Wystarczyło przesłać utwór i czekać na werdykt jurorów i internautów. Na zwycięzców - artystów czekała możliwość nagrania płyty, koncert $\mathrm{w}$ radiowej Trójce, nakręcenie teledysku lub profesjonalna sesja zdjęciowa. Internauci głosujący na wybrane utwory mogli z kolei wygrać iPody Touch, bilety na dowolne koncerty w Europie oraz škodę rapid spaceback [skodaautomuzyka.pl 2014]. Kolejna playlista kanału Škody na YouTube zatytułowana "Szkoła Auto" prezentuje nagrania przedstawiające techniki doskonalenia jazdy i jest związana z prowadzonym przez Škodę projektem pod tym samym tytułem. Przedsięwzięcie to polega na wspieraniu kierowców przez wykwalifikowanych instruktorów w zakresie rozwijania umiejętności bezpiecznej jazdy, eco drivingu oraz offroad drivingu. Ponadto w ramach L-drivingu oferowane są kursy nauki jazdy dla osób niepełnosprawnych [szkola-auto.pl 2014]. Przykład ten pokazuje, że profil na YouTube może być kanałem marki samochodowej pozwalającym na dotarcie do widza $\mathrm{z}$ rozmaitymi komunikatami, kanałem, dla którego marka będzie niejako dopełnieniem, a publikowane playlisty nie muszą zawierać jedynie znanych z telewizji, niedających widzom żadnej wartości dodanej reklam poszczególnych modeli samochodów. 
Kolejnym serwisem społecznościowym wpisującym się we wspomnianą kulturę obrazkową jest Pinterest. Stanowi on wirtualną wersję tablicy korkowej; przypina się na niej (nazwa pochodzi od ang. pin - przypinać) zdjęcia, filmy, notki, grafiki, które spodobały się lub zainspirowały do czegoś użytkownika [Krawiec 2013, s. 143]. Tłumacząc, czym jest Pinterest, w sposób metaforyczny można powiedzieć, że gdyby Internet miał lodówkę, to ten serwis byłby jej drzwiami, na których (tak jak w większości domów) przypina się różne informacje, wycinki, zdjęcia [Pinterest.com... 2012].

W branży motoryzacyjnej dobrym przykładem wykorzystania serwisu Pinterest była ogólnoeuropejska kampania związana z premierą nowego nissana micry. W lipcu 2012 roku firma Nissan zorganizowała konkurs mający na celu zaangażowanie klientów i zbudowanie $\mathrm{z}$ nimi więzi w mediach społecznościowych oraz wcielenie ducha „Micra Attiude” w życie. Konkurs był przeprowadzony w 16 europejskich krajach i skierowany do kobiet, co wiązało się z chęcią ukazania nissana micry jako idealnego samochodu dla pewnych siebie, inteligentnych, posiadających własny styl kobiet. Podkreślano udoskonalenia technologiczne samochodu, takie jak: dotykowy ekran, port USB, usługę Google Send-To-Car, a więc rozwiązania, których potrzebuje nowoczesna kobieta, lubiąca innowacyjne produkty, nowinki techniczne, pozostająca on-line i korzystająca z mediów społecznościowych. Wybór Pinteresta do kampanii Nissan uzasadniał tym, że jest to platforma skupiająca się na prezentacji wizualnej, która daje użytkownikom możliwość wyrażenia swojej osobowości, swoich zainteresowań czy pasji [Nissan... 2013]. Głównym celem konkursu nie było uzyskanie wysokiego ROI, a podkreślenie hasła przewodniego Nissana - „Innovation that excites”. Zadaniem uczestniczek konkursu było stworzenie na swym profilu w Pintereście własnej tablicy opatrzonej hashtagiem \#MicraAttitude i dodanie do niej zdjęć wyrażających osobowość, zainteresowania czy charakter uczestniczek w kontekście „Micra Attitude”. Aby przystąpić do konkursu, należało przypiąć do swojej tablicy od 8 do 15 zdjęć opatrzonych hashtagami \#MicraAttitude oraz \#Polska. Można było zamieścić więcej zdjęć, jednak w takim przypadku jury (pracownicy Nissana oraz agencji obsługującej projekt) brało pod uwagę jedynie 15 pierwszych fotografii. Sam konkurs promowany był na Facebooku przez posty sponsorowane (jest to kolejny przykład działań crossmediowych). W sumie w polskiej części konkursu zgłoszono około 20 tablic, a w konkursie wziął udział także jeden mężczyzna (finalnie jego tablica została oceniona jako jedna $\mathrm{z}$ lepszych). W każdym kraju wygrywały trzy osoby. Zwycięzcy otrzymywali tak zwany surprise pack, w którym był aparat fotograficzny oraz odtwarzacz MP3 firmy Sony. Rozdano także nagrody pocieszenia - zestawy z gadżetami firmowymi. Polska znalazła się w pierwszej piątce pod względem liczby uczestniczek (pierwsze trzy miejsca zajęły Wielka Brytania, Portugalia i Węgry) [Waś-Smyrgała 2013]. Jest to kolejny przykład prowadzenia niestandardowych działań komunikacyjnych w mediach społecznościowych. Na uwagę zasługuje to, że postawiono na serwis, który przez przeciętnego użytkownika Internetu nie jest kojarzony jako pierwszy 
z mediami społecznościowym. Jednak dzięki budowaniu zaangażowania, wpisującego się w istotę funkcjonowania Pinteresta, kampania odniosła sukces.

Ostatnim serwisem opierającym się na obrazie, o którym warto wspomnieć, jest Instagram. Zamieszczane w nim materiały mają charakterystyczny, kwadratowy kształt, który przywodzi na myśl stare zdjęcia $\mathrm{z}$ aparatów Polaroid [Kraciuk 2013]. Instagram, podobnie jak pozostałe serwisy społecznościowe, nie jest narzędziem uniwersalnym, które pasowałoby do każdej marki i każdej strategii komunikacji firmy z otoczeniem. Jego przydatność trzeba rozważać w odniesieniu do indywidualnego przypadku. Z pewnością musi to być sytuacja $\mathrm{z}$ ważną treścią wizualną, na której opiera się działanie serwisu [Insta-marketing 2012].

W świecie motoryzacyjnym ciekawą akcją wykorzystującą Instagram była kampania Forda o nazwie \#Fiestagram (warto zwrócić uwagę na nazwę hashtaga będącą kompilacją słów „Fiesta” - nazwy modelu forda będącego przedmiotem akcji - oraz „Instagram”), związana z rozwiązaniami high-tech w samochodzie. Koncern każdego tygodnia podawał nowy hashtag, którym fani mieli oznaczać zdjęcia związane $\mathrm{z}$ technologiami. Najlepsze zdjęcia ukazały się $\mathrm{w}$ galeriach oraz na billboardach, a nagrodą główną dla uczestników kampanii był ford fiesta [Ostrowska 2013]. Sam konkurs rozpoczęty w październiku 2011 roku na profilu globalnym forda fiesty na Facebooku miał na celu zapoznanie odbiorców z nowymi innowacyjnymi technologiami zastosowanymi w samochodzie na rok modelowy 2012. Zadaniem uczestników konkursu było robienie kreatywnych zdjęć za pomocą aplikacji Instagram, nawiązujących do cotygodniowych hashtagów określających cechę samochodu (\#hidden, \#shapes, \#music, \#starting, \#entry, \#listening). Hashtagi prezentowane były na stronie Facebooka. Zrobione zdjęcia, opatrzone hashtagiem specyficznym dla danego tygodnia oraz hashtagiem przewodnim kampanii - \#Fiestagram, były oceniane przez panel jurorski. Efektem kampanii było przedstawienie ponad 16 tysięcy zdjęć oraz pozyskanie ponad 120 tysięcy nowych fanów na Facebooku. Z punktu widzenia firmy projekt przyniósł też inne korzyści, budował bowiem świadomość marki i nowego modelu samochodu wśród odbiorców i popularyzował je, wpłynął także na utrzymanie oraz pielęgnację więzi wśród społeczności internautów [Klamm 2012; Żukowski 2012].

W Polsce kampanie z użyciem Instagrama nie są zbyt popularne, jednak można odnaleźć kilka ciekawych przykładów. Jednym z nich jest konkurs zorganizowany przez Hyundai Motor Poland pod nazwą „Upoluj Hyundaia”. Konkurs trwał od 7 czerwca do 8 lipca 2013 roku. Informacja o nim ogłoszona została na profilu firmy na Facebooku (rysunek 3.32). Konkurs polegał na zrobieniu zdjęcia samochodowi marki Hyundai za pomocą aplikacji Instagram oraz oznaczeniu go unikalnym hashtagiem \#upolujhyundaia. Uczestnicy mogli dodawać nieograniczoną liczbę fotografii, osoba, która zrobiła najwięcej zdjęć i zebrała najwięcej „lajków” w aplikacji Instagram, wygrywała smartfona Samsung Galaxy S4. Zwycięzca zrobił 207 zdjęć oraz uzyskał 313432 „lajków”, uczestnicy na kolejnych miejscach dodali 810 i 126 zdjęć, uzyskując odpowiednio 190100111963 „lajków” [Wilma 2013; Facebook. 
com 2013]. Osiągnięte wyniki świadczą o dużej popularności konkursu i potencjale wirusowym tego typu działań przy stosunkowo niewielkich nakładach, jakie firma musiała ponieść, realizując projekt.

Opisane powyżej serwisy społecznościowe przyczyniają się do ukazania marki przez pryzmat kultury obrazkowej. Zaprezentowany przegląd nie wyczerpuje w pełni tematu, może jedynie stanowić wstęp do szerszej dyskusji, ponieważ istnieje szereg tego typu portali. Za pomocą elementów wizualnych inspirują one użytkowników, oddziałują na ich emocje, sprawiają, że marki utrwalają się w umysłach konsumentów. Oddziaływanie wizualne wpływa także na procesy podejmowania decyzji zakupowych. W przypadku działań prowadzonych przez firmy istotny jest sam pomysł na kampanię w tych serwisach. Liczą się przede wszystkim działania nieszablonowe, kreatywne, wsparte odpowiednimi treściami - angażującymi i przeznaczonymi dla danego medium społecznościowego [Buczny 2012, s. 23].

\section{Informowanie na stronie WWW o wykorzystaniu mediów społecznościowych przez marki samochodowe w Polsce}

Przeprowadzony na potrzeby niniejszego opracowania autorski audyt polegał na poddaniu analizie zawartości stron internetowych marek samochodów istniejących na polskim rynku, które sprzedały w roku 2014 ponad 5 tysięcy samochodów (na podstawie danych publikowanych przez Instytut Badań Rynku Motoryzacyjnego SAMAR). Analizowano sposób komunikowania za pośrednictwem stron WWW o wykorzystywanych serwisach społecznościowych oraz umiejscowienie wtyczek do tych serwisów w strukturze strony. Nie sprawdzano, czy firma w ogóle posiada profil w danym serwisie, ale czy o tym fakcie komunikuje za pośrednictwem strony WWW (tabela 1). Przyjęto założenie, że podstawowym kanałem komunikacji firm motoryzacyjnych w sieci jest strona WWW, co wynika z tego, że najczęściej od niej zaczyna się kontakt internautów z daną firmą czy marką. Dlatego powinny znajdować się na niej także odnośniki do innych kanałów komunikacji elektronicznej, w tym serwisów społecznościowych.

Wtyczki do serwisów społecznościowych, tak zwane social plugin, przyciski like box czy like button są znane $\mathrm{z}$ licznych stron internetowych. Obecnie coraz popularniejsze (często wypierające te w wersji statycznej) są wtyczki w wersji wysuwającej się z prawej bądź lewej strony. Wtyczki generuje się na przykład na Facebooku, wypełniając prosty formularz - wówczas otrzymuje się gotowy kod, który następnie trzeba wkleić na firmową stronę WWW. Na większości badanych stron zamieszczono klasyczne wtyczki (w kształcie kwadratu z logo danego serwisu społecznościowego) w dolnej części strony (lub dolnym menu), w przypadku BMW było to lewe menu. Na stronie Mercedesa znalazły się dwie wtyczki (do Facebooka i YouTube) poniżej głównego banera strony, natomiast do innych serwisów zastosowano 
tradycyjne linki (z wykorzystaniem czcionek używanych na stronie), które wyglądem wpisują się w charakter strony - jej styl i design. Wszystkie linki społecznościowe zlokalizowano w zakładce strony głównej „Świat Mercedesa” - „Społeczności internetowe". Należy zaznaczyć, że w tym miejscu znajdują się linki do wielu profili (czasami w jednym serwisie) dla różnych brandów (np. AMG, Mercedes-Benz Museum), w większości prowadzonych w języku angielskim.

Tabela 1. Komunikowanie za pośrednictwem strony WWW o wykorzystywanych serwisach społecznościowych przez marki motoryzacyjne na rynku polskim (liczba 1 oznacza, że dana marka posiada wtyczkę do serwisu społecznościowego na swojej stronie WWW)

\begin{tabular}{|c|l|l|c|c|c|c|l|}
\hline Lp. & \multicolumn{1}{|c|}{ Marka } & Strona WWW & Facebook & YouTube & Instagram & Twitter & \multicolumn{1}{|c|}{ Inne } \\
\hline 1 & Audi & audi.pl & 1 & 1 & 1 & 1 & - \\
\hline 2 & BMW & bmw.pl & 1 & 1 & 1 & 1 & - \\
\hline 3 & Citroën & citroen.pl & 1 & 1 & - & 1 & $\begin{array}{l}\text { Pinterest, } \\
\text { G+ }\end{array}$ \\
\hline 4 & Dacia & dacia.pl & 1 & - & - & 1 & - \\
\hline 5 & Fiat & fiat.pl & 1 & 1 & - & 1 & Flickr, G+ \\
\hline 6 & Ford & ford.pl & 1 & 1 & 1 & - & - \\
\hline 7 & Honda & honda.pl & 1 & 1 & - & - & - \\
\hline 8 & Hyundai & hyundai.pl & 1 & 1 & - & - & - \\
\hline 9 & Kia & kia.pl & 1 & 1 & - & - & G+ \\
\hline 10 & Mazda & mazda.pl & 1 & 1 & - & - & Mazda \\
\hline 11 & Mercedes & mercedes.pl & 1 & 1 & 1 & 1 & Pinterest, \\
\hline 12 & Mitsubishi & mitsubishi.pl & 1 & 1 & - & 1 & - \\
\hline 13 & Nissan & nissan.pl & 1 & 1 & - & 1 & - \\
\hline 14 & Opel & opel.pl & 1 & 1 & - & - & - \\
\hline 15 & Peugeot & peugeot.pl & 1 & 1 & - & - & LinkedIn \\
\hline 16 & Renault & renault.pl & 1 & - & - & - & - \\
\hline 17 & Seat & seat-auto.pl & 1 & 1 & - & - & - \\
\hline 18 & Škoda & skoda.pl & 1 & 1 & - & - & - \\
\hline 19 & Suzuki & suzuki.pl & 1 & 1 & - & - & - \\
\hline 20 & Toyota & toyota.pl & 1 & 1 & - & 1 & LinkedIn \\
\hline 21 & Volkswagen & volkswagen.pl & 1 & 1 & - & - & G+ \\
\hline 22 & Volvo & volvocars.com.pl & 1 & 1 & 1 & - & G+ \\
\hline & Razem & & 22 & 20 & 5 & 9 & 9 \\
\hline & & & & & & & \\
\hline & & & & & & & \\
\hline
\end{tabular}

Źródło: opracowanie własne. 
Wszystkie profile w serwisach społecznościowych, do których badane marki zamieściły wtyczki na swoich stronach WWW, były prowadzone aktywnie. Każda z 22 analizowanych marek ma profil na Facebooku, przy czym niektóre, jak KiaA, mają łącza także do innych profili związanych z działalnością sponsoringową marki (w przypadku Kii do trzech: „KiaA Lotos Race” - cyklu wyścigów, „Świat Tenisa” - związanego ze sponsoringiem Australian Open i „Kocham Football” - związanego ze sponsoringiem Euro 2016). O własnym kanale na YouTube na stronie firmowej komunikuje 21 marek, chociaż w przypadku Renault wtyczka nie jest widoczna z poziomu strony głównej, a dopiero po kliknięciu zakładki „Kontakt” i dalej „Dołącz do nas”. Swojego kanału w serwisie nie ma jedynie Dacia, jednak filmy poświęcone tej marce odnaleźć można na kanale Renault Polska (Dacia jest marką należącą do Grupy Renault). Podobnie jest z profilami w innych serwisach społecznościowych. Jak wspomniano wcześniej, nie zawsze ich istnienie jest komunikowane na firmowej stronie WWW. W takim wypadku można to uznać za błąd $\mathrm{w}$ strategii komunikacji, ponieważ $\mathrm{w}$ ten sposób marki te nie wykorzystują potencjału własnych serwisów internetowych do kierowania swoich klientów bądź innych grup odbiorców do tych profili. Umieszczenie wtyczki do własnego profilu w danym serwisie społecznościowym jest najprostszym sposobem jego promocji.

Komunikowanie o innych serwisach społecznościowych niż wymienione wcześniej Facebook i YouTube, podobnie jak samo ich wykorzystanie, jest znacznie skromniejsze. O profilu na Twitterze informuje dziewięć marek, jednak w przypadku Citroëna jest to profil prowadzony w języku angielskim, w przypadku Fiata - po angielsku i włosku, a Dacii - po francusku. Na swoich stronach dziewięć spośród analizowanych marek zamieszcza informację o wykorzystaniu także innych serwisów: pięć razy pojawia się Google+, dwa razy Pinterest, tyle samo LinkedIn, służący do budowania sieci networkingowej, i raz Flickr.

Interesującym przypadkiem jest serwis Mazda Rebels, będący swoistym portalem społecznościowym; jego główną ideą jest „utworzenie otwartej przestrzeni, w której uczestnicy mogą wymieniać się pomysłami z ludźmi myślącymi w podobny sposób" (mazda.pl, dostęp: 15.05.2015). Jest to platforma gromadząca osoby chcące łamać pewne stereotypy, aby zmieniać świat na lepsze, co wiąże się z ogólną filozofią japońskiej firmy.

\section{Podsumowanie}

Przytoczone $\mathrm{w}$ artykule przykłady wykorzystania serwisów społecznościowych w komunikacji marketingowej marek motoryzacyjnych pokazują, jak duży jest w nich potencjał, jeśli chodzi o nawiązywanie bliższych relacji z odbiorcami, w szczególności klientami i/lub fanami poszczególnych marek czy modeli samochodów. Wymienione serwisy nie zaspokajają zapotrzebowania $w$ tej dziedzinie, jednak pokazują pewien kierunek komunikacji. Najważniejsze są niestandardowe 
działania budujące zaangażowanie odbiorców, a w przypadku treści prosprzedażowych umiejętne ich opakowanie, aby uniknąć wrażenia nachalnej reklamy.

W związku $z$ dużą konkurencją w branży widoczne jest znaczne i aktywne wykorzystanie szeroko pojętych mediów społecznościowych przez firmy motoryzacyjne, chociaż zauważalne są też pewne niedociągnięcia, jak brak profili polskojęzycznych w niektórych serwisach. Część marek obok prowadzenia typowych czy wręcz obecnie obowiązkowych profili w popularnych serwisach społecznościowych próbuje wyznaczyć własną ścieżkę, jak Mazda ze swoją platformą Mazda Rebels czy Škoda ze Škodovym Blogiem, wracająca do nieco już zapomnianych blogów korporacyjnych. To wszystko pokazuje, jak wiele pozostaje nieodkryte w zakresie komunikacji społecznościowej w ogóle. Z pewnością marki samochodowe jeszcze wielokrotnie zaskoczą swoich odbiorców w tym zakresie.

\section{Bibliografia}

Brunk K.H. (2010), Reputation building: beyond our control? Inferences in consumers' ethical perception formation, „Journal of Consumer Behaviour”, vol. 9, iss. 4, s. 275-292.

Buczny E. (2012), Reguly kontentu w sieci, „Marketing w Praktyce”, nr 12, s. 23-25.

Evans D.S., Schmalensee R. (2010), Kod katalizatora. Strategie najbardziej dynamicznych firm świata, tłum. M. Rostocki, Wolters Kluwer Polska, Warszawa.

Evans L. „Li” (2011), Social media marketing. Odkryj potencjał Facebooka, Twittera i innych portali społecznościowych, tłum. B. Sałbut, Helion, Gliwice.

Facebook.com (2013), https://www.facebook.com/HyundaiPolska/app_523564411025985 (dostęp: 11.09.2013).

Hughes M. (2008), Marketing szeptany. Z ust do ust. Jak robić szum medialny wokót siebie, fir$m y$, produktu, tłum. T. Rzychoń, Wydawnictwo MT Biznes, Warszawa.

Insta-marketing (2012), OX Press, 25.10.2012, http://oxpress.pl/insta-marketing/ (dostęp: 10.03.2014).

Jakubiak Ł. (2014), Rola obrazów w kreowaniu wizerunku, http://www.epr.pl/rola-obrazow-w-kreowaniu-wizerunku,felietony,1046,1.html (dostęp: 14.06.2014).

Klamm D. (2012), How Ford Used Instagram to Promote the Fiesta's High-Tech Features, 2.02.2012, http://mashable.com/2012/02/02/ford-fiesta-instagram/ (dostęp: 14.09.2013).

Kraciuk P. (2013), Co to jest Instagram? - ABC Instagram cz. 1, Enzo, 18.12.2013, http://enzo. $\mathrm{pl} / 2013 / 12 / 18 /$ co-to-jest-instagram/ (dostęp: 11.02.2014).

Krawiec W. (2013), Kultura obrazka a zaangażowanie konsumenta $w$ proces budowania marki na przykładzie portalu społecznościowego Pinterest, [w:] W. Grzegorczyk (red.), Marketing w obliczu nowych wyzwań rynkowych. Ksiega jubileuszowa z okazji 70-lecia profesora Bogdana Gregora, Wydawnictwo Uniwersytetu Łódzkiego, Łódź.

metricsman, http://metricsman.worldpres.com.

Nissan poszukuje ducha „Micra Attitude” w serwisie Pinterest (2013), NowyMarketing, 15.07.2013, http://nowymarketing.pl/a/2126,nissan-poszukuje-ducha-micra-attitude-w-serwisie-pinterest (dostęp: 18.10.2013).

Ostrowska K. (2013), Instagram: obraz rośnie w siłe. Czy jesteśmy w trakcie rewolucji wizualnej?, Socjomania, 18.06.2013, http:socjomania.pl/Instagram-obraz-rosnie-w-sile-czy-jestesmy-w-trakcie-rewolucji-wizualnej/ (dostęp: 11.07.2013). 
Pająk A. (2014), Ox Media/Volkswagen Polska. Gaz do dechy na Facebooku!, „Marketing w Praktyce", nr 6, s. 73-76.

Pinterest.com - przeczytaj zanim wejdziesz (2012), Newsweek.pl, 25.02.2012, http://technologie.newsweek.pl/pinterest-com---przeczytaj-zanim-wejdziesz,88739,1,1.html (dostęp: 28.02.2012).

Podlaski A. (2011), Marketing społecznościowy. Tajniki skutecznej promocji w social media, Wydawnictwo Helion, Gliwice.

Rak A. (2011), Facebook, przyjaciel czy wróg przedsiębiorstwa, [w:] Z. Waśkowski (red.), Komunikacja rynkowa. Kultura, perswazja, technologia, Zeszyty Naukowe Uniwersytetu Ekonomicznego w Poznaniu, nr 209, Wydawnictwo Uniwersytetu Ekonomicznego, Poznań, s. $96-106$.

Rak B. (2012a), 21 sposobów na pozyskanie fanów w serwisie Facebook, „Marketer+”, nr 3, s. $62-67$.

Rak B. (2012b), Czy Facebook sprzedaje?, „Marketing w Praktyce”, nr 6.

skodaautomuzyka.pl (2014), http://skodaautomuzyka.pl/pl/zglos-utwor/\#zasady (dostęp: 7.04.2014).

szkola-auto.pl (2014), http://www.szkola-auto.pl/kompetencje (dostęp: 7.04.2014).

Waś-Smyrgała J. (2013), Konkurs \#MicraAttitude na Pintereście - case study, NowyMarketing, 29.11.2013, http://nowymarketing.pl/a/2634,konkurs-micraattitude-na-pinterescie-case-study (dostęp: 18.01.2014).

Wilma A. (2013), Trendy na Instagramie w Polsce, NowyMarketing, 7.08.2013, http://nowymarketing.pl/a/2040,trendy-na-instagramie-w-polsce (dostęp: 11.09.2013).

Woźniakowski M. (2013), Pinterest jako przejaw kultury obrazkowej w komunikacji marketingowej przedsiębiorstw, [w:] W. Grzegorczyk (red.), Marketing w obliczu nowych wyzwań rynkowych. Ksiega jubileuszowa z okazji 70-lecie profesora Bogdana Gregora, Wydawnictwo Uniwersytetu Łódzkiego, Łódź.

Żukowski M. (2012), Instagram $w$ stużbie marketingu, media2, 5.04.2012, http://media2.pl/reklama-pr/90691-Instagram-w-sluzbie-marketingu.html (dostęp: 15.09.2013). 